International Journal of Instruction

e-ISSN: 1308-1470 • www.e-iji.net

Article submission code

20191003044446

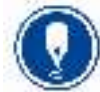

January $2021 \bullet$ Vol.14, No.1

p-ISSN: 1694-609X

pp. $17-28$

Received: 03/10/2019

Revision: 30/05/2020
Accepted: 21/06/2020

OnlineFirst:05/10/2020

JiRQA Learning Model of Based Gender: Cognitive Learning Students in Environmental Pollution Material

\title{
Yakobus Bustami
}

Dr., corresponding author, Biology Education Study Program, STKIP Persada Khatulistiwa Sintang, Indonesia, ybustami07@gmail.com

Florentina Rahayu Esti Wahyuni

Biology Education Study Program, STKIP Persada Khatulistiwa Sintang, Indonesia, estipandi84@gmail.com

\section{Didin Syafruddin}

Biology Education Study Program, STKIP Persada Khatulistiwa Sintang, Indonesia, didinsyafruddin28@gmail.com

\section{Marsela}

Biology Education Study Program, STKIP Persada Khatulistiwa Sintang, Indonesia, smar71148@gmail.com

\section{Taslim D. Nur}

Faculty of Teacher Training \& Education, Universitas Khairun Ternate, Indonesia, taslimrezmit76@gmail.com

The research aimed to uncover the effect of JiRQA learning a model of based gender on students' achievement at the environmental pollution material. The method was quasy-experimental using of $2 \times 2$ factorial. The population was all students at junior high school from Ketungau Tengah, Indonesia. The samples were 120 students from two separate schools which represented gender differently. The instrument using a multiple-choice test. Data were analyzed using descriptive and inferential analysis. The results of the descriptive analysis show that the average pre-test of achievement in the experimental and control classes both male and female genders have the same value category and post-test in the control classes have a different value category. The results of ANCOVA show that the learning model had a significant effect on achievement, while gender and the interaction of learning models and gender did not have a significant effect on achievement. Classes that use the JiRQA learning model have a higher and significantly different from conventional classes.

Keywords: JiRQA learning, cooperative, gender, cognitive learning, biology students

Citation: Bustami, Y., Wahyuni, F. R. E., Syafruddin, D., Marsela, \& Nur, T. D. (2020). JiRQA Learning Model of Based Gender: Cognitive Learning Students in Environmental Pollution Material. International Journal of Instruction, 14(1), 17-28. https://doi.org/10.29333/iji.2021.1412a 


\section{INTRODUCTION}

The development facing science and technology in the 21st century requires the quality of human resources that can be obtained through education. Education quality can be reflected in graduates who can compete globally and able to knowledge master and technology development (Kanematsu \& Barry, 2016). Knowledge mastery can be achieved if the teacher can maximize student cognitive learning results.

Cognitive learning results are knowledge obtained by students after doing the teaching and learning process. Cognitive learning results be the spotlight of the public because related to knowledge and intellectuals (Anderson \& Krathwohl, 2001). Cognitive learning results have a role in the learning process and everyday life (Bustami, 2017). Student cognitive learning results are related to students' ability to use conceptual understanding (Lestari, et.al., 2019). Cognitive learning results be benchmarks for teachers to know students' understanding of the material that has been given. Therefore, the cognitive abilities of students need to be improved.

However, in reality, the results of pre-observation show the cognitive learning results of biology students in junior high school have not been maximized. The classical value of biology students has not reached $50 \%$. Besides, the results of research by Hadizah \& Muhfahroyin (2012) also showed that 18 students did not experience minimum completeness of 33 students.

Factors causing the low of biology students' cognitive learning results include: (1) students perceive biology as a complex subject and many Latin languages. (2) students are less concentrated in the learning process, (3) students have the habit of coming to school without material preparation, (4) low interest in reading, (5) the learning process that is done tends to conventional that is only done in one direction which causes more centered learning on the teacher so that it will affect the low of biology students cognitive learning results.

Inel \& Balim (2010) and Bahri (2016) revealed that the factors that cause the low of biology student learning results were due one-way learning process, conventional learning, and passive students, as well as the tendency to be teacher-centered. Nuraisah, et.al., (2016) and Bustami, et.al., (2018) that the conventional learning process places students as learning objects that act as passive recipients of the information. Conventional learning is only centered on the teacher without the element of student activity in the teaching and learning process. Corebima (2016) also revealed that the process of learning biology tends to the only lecture, conduct questions and answers, give assignments and apply various other techniques without being related to any model or learning strategy.

Hamid, et.al., (2014) revealed the low of biology students' cognitive learning results because the learning process undertaken is mostly still teacher-centered so that the teacher dominates activities of teaching and learning. This if left unchecked can affect the low of education quality, especially cognitive learning results. Besides, several kinds of research showed that gender also affects learning results. Hadjar, et.al., (2014) revealed that gender affects the achievement of students. This is in line with Jackman \& 
Webb (2019) and Gustavsen \& Margareth (2019) who showed that there was a gender effect on the achievement of school students. The current research showed that there are different conceptions of learning science between genders, in which females tend to use more memorization than male students in learning science (Rachmatullah, et.al., 2017).

There is a relationship between gender with students' academic abilities (Bikar, 2018 and Saban, et.al., 2019). Female students were determined to have more success than male ones. Female students are better able to remember and have better cognitive learning results than male students so there is a gap between male students and female students (Nierderle \& Vesterlund, 2011). Mahanal, et.al., (2018) also revealed that the problem of being associated with gender gaps was not yet given much attention by teachers. This can be seen from teachers who have never designed learning that can empower the equality of achievement in male and female students. Vassilou (2009), showed that the making of summaries in the form of concept maps has more role for spatial intelligence in men while in women is more feminist that contains many words (verbal) so that it will be able to influence learning results especially cognitive learning results.

Therefore, it needs a breakthrough to create an innovative learning process that can accommodate gender differences, one of which is the JiRQA learning a model. The JiRQA learning model is one of the cooperative learning models that are the integration result of the syntax between the jigsaw learning and Reading, Questioning, Answering (RQA) learning (Bustami, et.al., 2017). This learning process is believed can to improve students' cognitive abilities. Cognitive abilities increased due to students "forced" to read the material to be studied (Corebima, 2009).

The reading process will expand its cognitive through their thinking ability. Besides, JiRQA learning a model can create learning that is fun and meaningful for students (Bustami, 2017). JiRQA learning model type cooperative involves all students to actively learn and accommodate all the differences in the class, including gender differences. Active involvement of all students in JiRQA learning will be able to improve student learning results, especially cognitive learning results (Bustami, 2017).

Based on this background it is necessary to conduct research using the JiRQA learning a model of based gender to determine student cognitive learning results. This research is expected to information provided to teachers to implement various innovative learning models to improve the cognitive abilities of students who have gender differences.

\section{METHOD}

\section{Research Design}

This research used a quasy-experiment design. The experimental design in the form of pretest-posttest nonequivalent control groups design of $2 \times 2$ factorials. The first factorial was JiRQA learning and conventional learning. The second factorial was gender, consisting of male and female genders. The research pretest-posttest nonequivalent control groups of 2 x 2 factorial design can be seen in Table 1 . 
Table 1

The Quasy-Experiment Design of Factorial

\begin{tabular}{|c|c|c|c|}
\hline Pre-test & Treatments & Post-test & \\
\hline $\mathrm{O} 1$ & $\mathrm{~S}_{1} \mathrm{Y}_{1}$ & $\mathrm{O} 2$ & \\
\hline $\mathrm{O} 3$ & $\mathrm{~S}_{1} \mathrm{Y}_{2}$ & $\mathrm{O} 4$ & \\
\hline O5 & $\mathrm{S}_{2} \mathrm{Y}_{1}$ & O6 & \\
\hline $\mathrm{O} 7$ & $\mathrm{~S}_{2} \mathrm{Y}_{2}$ & O8 & \\
\hline \multicolumn{4}{|l|}{ Note: } \\
\hline $\mathrm{O} 1, \mathrm{O} 3, \mathrm{O} 5, \mathrm{O} 7$ & : Pre-test scores & S2 & : Conventional learning \\
\hline $\mathrm{O} 2, \mathrm{O} 4, \mathrm{O} 6, \mathrm{O} 8$ & : Post-test scores & Y1 & : Male Gender \\
\hline $\mathrm{S} 1$ & : JiRQA learning & $\mathrm{Y} 2$ & : Female Gender \\
\hline
\end{tabular}

\section{Population and Sample of the Research}

The population in this research was all students of class VII junior high school which consisted of two schools from Ketungau Tengah, Sintang District, West Kalimantan, Indonesia. The samples were 120 students with consisted of 63 female students and 57 male students. Determination of the sample using the simple random sampling technique based on the results of the placement test. Placement test results show that the probability value was greater than alpha 0.05 , so it can be concluded that all samples had an equal (homogeneous) academic ability.

\section{Research Instrument}

The research instrument used to measure the biology students' cognitive learning results were in the form of a multiple-choice test as many as 30 items. The research instrument used had been validated both contents, construct and empirical. The test results show that all items were valid and reliable with a reliability value was 0.94 with a very high category.

\section{Research Procedures}

The research procedures consisted of three stages. The first stage was the stage of giving a pre-test, giving a pre-test to see the initial abilities of students before the implementation of JiRQA learning and conventional learning. The second stage was the implementation process of JiRQA learning and conventional learning as much as two meetings on environmental pollution material. The third stage was the stage of giving a post-test, giving a post-test to see the student's final ability after the learning process.

\section{Data Analysis}

The data were analyzed using descriptive statistical analysis and inferential statistical analysis. Descriptive analysis to see the average value of cognitive learning results while inferential analysis to see the results of hypothesis testing using ANCOVA. Improved learning results in each group were analyzed using the gain index. Before conducting the hypothesis test, the prerequisite test was normality and homogeneity tests. All data related to the cognitive learning results biology student were analyzed using the SPSS version 18 program. 


\section{FINDINGS}

The results of the descriptive analysis show that the average pre-test of cognitive learning results in the experimental and control classes both male and female genders has the same value category that was very low. The average post-test of cognitive learning results in the experimental class both male and female genders has the same value category, which was good, while the control class on male gender has enough category and female was a low category. The descriptive analysis results can be seen in Table 2.

Table 2

Summary of Mean Pre-test and Post-test Cognitive Learning Results

\begin{tabular}{lllllll}
\hline Learnings & Genders & $\begin{array}{c}\text { Samples } \\
\text { Total }\end{array}$ & $\begin{array}{c}\text { Average } \\
\text { Pre-test }\end{array}$ & Category & $\begin{array}{c}\text { Average } \\
\text { Post-test }\end{array}$ & Category \\
\hline \multirow{2}{*}{ JiRQA } & Female & 30 & 34.77 & Very low & 74.66 & Good \\
\cline { 2 - 7 } & Male & 30 & 35.11 & Very low & 74.44 & Good \\
\hline \multirow{2}{*}{ Conventional } & Female & 33 & 34.04 & Very low & 60.19 & Low \\
\cline { 2 - 7 } & Male & 27 & 33.45 & Very low & 64.19 & Enough \\
\hline
\end{tabular}

The results of ANCOVA show that the learning model (p: 0.000) had an significant effect on cognitive learning results (p: $0.000<0.005)$, while gender (p: 0.539) and the interaction of learning and gender models (0.726) did not have a significant effect on cognitive learning results because the probability value is greater than alpha 0.005 . The results of ANCOVA indicate that there are differences in students' cognitive learning results between classes using the JiRQA and conventional learning models. Classes that use the JiRQA learning model have a higher gain index value (0.61) and significantly different from conventional classes. The summary of ANCOVA test results can be seen in Table 3.

Table 3

Summary of ANCOVA Student Cognitive Learning Results

\begin{tabular}{llllrl}
\hline Source & Type III Sum of Squares & df & Mean Square & F & Sig. \\
\hline Corrected Model & $3613.758^{\mathrm{a}}$ & 4 & 903.440 & 20.958 & .000 \\
\hline Intercept & 31411.725 & 1 & 31411.725 & 728.696 & .000 \\
\hline Cognitive Pre-test & 11.105 & 1 & 11.105 & .258 & .613 \\
\hline Strategy & 3496.152 & 1 & 3496.152 & 81.104 & .000 \\
\hline Gender & 16.387 & 2 & 16.387 & .380 & .539 \\
\hline Strategy * Gender & 31.306 & 2 & 31.306 & .726 & .396 \\
\hline Error & 4957.278 & 115 & 43.107 & & \\
\hline Total & 592894.801 & 120 & & & \\
\hline Corrected Total & 8571.037 & 4 & & & \\
\hline
\end{tabular}

The results of the gain index in Table 4. show that there was an increase in student cognitive learning results in male and female genders. The results of the gain index related gender show that the male gender has a gain index was 0.54 and higher than the female students was 0.49 . These results can be concluded that the cognitive learning results of male students were better than the cognitive learning results of female students even though there did not have a significant difference. 
Table 4

Summary of Average Cognitive Learning Results-Based Gender

\begin{tabular}{|c|c|c|c|c|c|}
\hline \multirow[b]{2}{*}{ Genders } & \multicolumn{5}{|l|}{ Average Value } \\
\hline & Pre-Cognitive & Post-Cognitive & Differences & Gain & Category \\
\hline Female & 34.39 & 67.08 & 32.69 & 0.49 & Enough \\
\hline Male & 34.32 & 70.11 & 35.79 & 0.54 & Enough \\
\hline
\end{tabular}

Related to the interaction of learning models and gender, although it was proved to have no effect of interaction between learning models and gender on cognitive learning results, but after computation the gain index results show that there are differences in the categories of cognitive learning results in conventional learning groups with female gender being low category and male gender are enough category, whereas in the JiRQA learning model group with gender there is no difference in the value category, namely the high category. The summary of the average cognitive learning results based on the computation of the gain index on the interaction of learning models and gender can be seen in Table 5.

Table 5

Summary of Average Cognitive Learning Results-Based Interaction of Learning and Gender

\begin{tabular}{|c|c|c|c|c|c|c|}
\hline \multirow[b]{2}{*}{ Learnings } & \multirow[b]{2}{*}{ Genders } & \multicolumn{2}{|c|}{ Average Value } & \multirow{2}{*}{\multicolumn{2}{|c|}{ Differences Gain }} & \multirow[b]{2}{*}{ Category } \\
\hline & & Pre-Cognitive & Post-Cognitive & & & \\
\hline \multirow[t]{2}{*}{ Conventional } & Female & 34.04 & 60.19 & 30.12 & 0.39 & Low \\
\hline & Male & 33.45 & 64.19 & 30.75 & 0.46 & Enough \\
\hline \multirow[t]{2}{*}{$\overline{\text { JiRQA }}$} & Female & 34.77 & 74.66 & 39.89 & 0.61 & High \\
\hline & Male & 35.11 & 75.44 & 40.33 & 0.62 & High \\
\hline
\end{tabular}

\section{DISCUSSION}

The results of the descriptive analysis show that there had an increase in student cognitive learning results both in the experimental class and the control class. The average pre-test of students cognitive learning results in the experimental and control classes fall into the very poor category namely the experimental class was 34.94 and the control class was 33.77, while the average post-test for the experimental class students was 75.11 with good category and the control class was 64.11 with enough category. The average value of students' cognitive learning results in the experimental class increased by 40.17 while the control class increased by 30.34 . The results of this research describe that learning using the JiRQA learning model has improved cognitive learning results better than conventional learning. The results of this research are in line with research by Bustami (2017) revealed that JiRQA learning could improving cognitive learning results. Futhermore, the research results by Safitri, et.al., (2018); and Muhlis (2018) revealed that jigsaw learning strategies are more able to improve cognitive learning results compared to conventional learning strategies. The same thing was done by Haerullah \& Usman (2013); Akmalaya \& Hapsari (2016); Bahri (2016); Corebima (2016) also showed that RQA learning strategies can improve student cognitive learning results. 
The results of ANCOVA show that the learning model (p: 0.000) has a significant effect on cognitive learning results (value: $\mathrm{p}<0.005$ ). These results indicate that there are differences in students' cognitive learning results between classes using JiRQA and conventional learnings. Classes that use the JiRQA learning model have a higher gain index value (0.61) and are significantly different from conventional classes. Thus, the implementation of the JiRQA learning model can improve cognitive learning results compared to conventional learning.

Cognitive learning results in the experimental class have increased because the JiRQA learning model has more advantages in the syntax of learning, especially in reading, making questions and answers questions as well as expert groups so that more studentcentered learning, students will more active and finally able to improve student cognitive learning results. Bustami \& Corebima (2017) said that the advantages of the JiRQA learning model lie in the characteristics of each learning phase. The conventional learning process is more tends to be one way causing the learning process to become ineffective and more dominated by teachers, so students become less active and creative.

The JiRQA learning model directs students to make resumes so students become active and could improve cognitive learning results. This is in line with research Corebima (2009) revealed that in making resumes students have gone through several processes namely listening, seeing, writing and expressing the material being studies. Thus, of course, students could be active and easier to understand and remember the material being studied. Mahapatra (2015) also revealed that an increase in cognitive learning results could be achieved through the stages of reading activity.

Furthermore, JiRQA learning has original groups and expert groups that can make students active in discussions and expert groups would be tutors for the original groups causing students to exchange information that will form an almost identical understanding of the material learned. This is in line with Saputra (2019) which states that the jigsaw learning strategy was a combination of several experts and expert groups, namely groups consisting of members of different origin groups who are assigned to study and explore certain topics according to their part and then explained to original group members. So, students not only learn the material they receive, but they must also be prepared to give and teach the material they have received. Zubaidah \& Corebima (2016) said that the main purpose of cooperative learning in school was to make each student a learner individual through social interaction with others (peers and teachers) and actively participate in the tasks given.

The stages in implementing the JiRQA learning model could make students more active, creative and courageous to appear so that the learning process would be more meaningful. Every student would be able to master the subject matter well due to the fun learning process. This proves that the implementation of the JiRQA learning model could significantly improve cognitive learning results.

The results of ANCOVA related to the effect of gender on cognitive learning results show that gender had no significant effect on cognitive learning results. The results of the gain index related gender show that the male gender has a gain index was 0.54 and 
higher than the female students was 0.49 . These results can be concluded that the cognitive learning results of male students were better than the cognitive learning results of female students even though there did not have a significant difference. The results of this research are in line by Darmawan (2017) revealed that there had no significant gender effect on cognitive learning results.

The absence of gender influence on cognitive learning results in this research due to gender, academic achievement, and socioeconomic status that did not affect students' thinking abilities (Heong, et al, 2011). The gender that does not affect can be interpreted that the learning model that is carried out was able to minimize gender differences through learning so those male and female students could achieve relatively similar cognitive learning results.

Vassilou (2009) revealed that the make of summary in the form of concept maps has more role for spatial intelligence in male, whereas biology lessons themselves are feminist learning that contains many words (verbal), where female are superior, but this research shows that the value of male and female students there is no significant difference in cognitive learning results. This is because male and female students who are used as research samples have characters that are not much different. Male and female students alike have spatial intelligence and verbal abilities.

On the other hand, male and female students in junior high school in Ketungau Tengah could cooperate, so that cognitive learning outcomes are not much different. According to Bustami (2017), students who are able to work together in the learning process will be able to equalize cognitive learning outcomes.

Related to the interaction of learning models and gender show that the interaction of learning and gender models did not have a significant effect on cognitive learning results. Although it was proved to have no effect of interaction between learning models and gender on cognitive learning results, but after the results of gain index show that there are differences in the categories of cognitive learning results in conventional learning groups with female gender being low category and male gender are enough category, whereas in the JiRQA learning model group with gender there is no difference in the value category, namely the high category.

The research results prove that the implementation of the JiRQA learning model is cooperative learning can equalize and improve the cognitive learning results of both male and female students. This is in line with research Bustami (2017) revealed that the implementation JiRQA learning could improve the cognitive learning results of students that have character ethnics, genders, and achievement different. The research results by Purwaningsih (2017) and Darmawan (2017) also showed that the interaction between NHT remap (cooperative learning) and gender did not significantly influence learning results.

This is due to the JiRQA learning process which is part of cooperative learning that is can teach students to learn from one another in different genders. Furthermore, it is because the syntax of the JiRQA learning model makes students more active in the 
learning process both in making resumes and discussion activities in the original and expert groups so that students can reconstruct what they learn into knowledge and naturally would enter into a long term memory (Bustami, 2017). Thus, it is expected to be able to implement the JiRQA learning model type of cooperative to improve cognitive learning results in male and female students.

\section{CONCLUSION}

Based on the results of data analysis and discussion, it can be concluded: (1) The JiRQA learning model influences students' cognitive learning results. The increase in the mean gain index in classes using the JiRQA learning model was higher and significantly different than the conventional learning group. (2) Gender does not affect the increase in cognitive learning results for both male and female students. (3) The interaction of learning models with gender does not affect cognitive learning results in the classroom by using the JiRQA learning model but is significantly different in the conventional learning group combination with gender. Thus, the JiRQA learning model has the potential to improve and equate cognitive learning results for students with different gender backgrounds.

\section{ACKNOWLEDGMENT}

The authors thank the chairman of teacher training college of the STKIP Persada Khatulistiwa Sintang who has given permitted and the financial support to conduct research. Thanks also to head school and biology teacher at middle school in Ketungau Tengah and who has given permitted and helped researchers to conduct research.

\section{REFERENCES}

Akmalaya, N. I., \& Hapsari, A. I. (2016). Learning model reading questioning and answering (RQA) to improve students achievement. Jurnal Biologi dan Pembelajaran Biologi, 1(1), 69-80.

Anderson, L. W., \& Krathwohl, D. R. (2001). A taxonomy for learning, teaching and assesing; A revision of bloom's taxonomy of educational objectives. NY: Addison Wesley Longman.

Bahri, A. (2016). Reading questioning and answering (RQA) learning strategy on animal physiology course to enhance students' cognitive learning outcome. Jurnal Bionature. 17(2), 107-114.

Bahtiar. (2013). The potential of learning strategy integrating Think Pairs Share (TPS) and Reading Questioning Answering (RQA) to improve the social attitude and biological concept mastery of multiethnic senior high school students in Ternate. Proceeding Seminar Nasional X Biologi UNS Surakarta, 10(2), 48-54.

Bikar, S., Marziyeh, A., \& Pourghaz, A. (2018). Affective structures among students and its relationship with academic burnout with emphasis on gender. International Journal of Instruction, 11(1), 183-194. 
Bustami, Y. (2017). The Effect of JiRQA learning strategy on cognitive achievement, critical thinking skills, and social attitude multiethnic students in zoology lecture at STKIP Persada Khatulistiwa Sintang (Unpublished doctoral dissertation). University of Malang.

Bustami, Y., \& Corebima, A. D. (2017). The effect of JiRQA learning strategy on critical thinking skills of multiethnic students in higher education, Indonesia. International J of Humanities Social Science and Education (IJHSSE), 4(3),13-22.

Bustami, Y., Corebima, A. D., Suarsini, E., \& Ibrohim (2017). The social attitude empowerment of biology students: implementation JiRQA learning strategy in different ethnics. International Journal of Instruction, 10(3), 15-30.

Bustami, Y., Syafruddin, D., \& Afriani, R. (2018). The implementation of contextual learning to enhance biology students' critical thinking skills. Jurnal Pendidikan IPA Indonesia, 7(4), 451-457.

Corebima, A. D. (2009). Experience trying to become a professional teacher, professor inaugural speech in the field of genetics. Malang: FMIPA Universitas Negeri Malang.

Corebima, A. D. (2016). Learning biology in Indonesia is not for life. Proceeding Biology Edu Conference: Biology, Science, Environmental, and Learning, 13(1), 8-22.

Darmawan, E., Brasilita, Y., Zubaidah, S., \& Saptasari, M. (2017). Enhancing metacognitive skills of students with different gender using simas eric learning model at state senior high school 6 Malang. Biosfer: Jurnal Pendidikan Biologi, 11(1), 47-56.

Gustavsen, \& Margareth, A. (2019). Gender differences in academic achievement: A matter of contextual classroom influence? Int J of Res Studies in Education, 8(1), 1-20.

Hadjar, A., Schwerdt, S. K., Priem, K., \& Glock, S. (2014). Gender and educational achievement. Journal Educational Research, 56(2), 117-125.

Haerullah, A., \& Usman, F. H. (2013). The effect of the implementation of the reading questioning and answering (RQA) model to the metacognitive knowledge of grade XI science students of SMA Negeri 2 Ternate city. Jurnal Bioedukasi, 2(1), 180-184.

Hadizah, E., \& Muhfahroyin. (2012). Improve the ability of meta cognition and biology learning outcomes of PGRI 1 Punggur high school students through the application of the guided inquiry method (Guide Inquiry). Bioedukasi, 3(2), 1-10.

Heong, Y. M., Othman, W. B., Yunos, J. M., Kiong, T. T., Hassan, R. B., \& Mohamad, M. M. B. (2011). The level of Marzano higher order thinking skills among technical education students. Int Journal of Social Science and Humanity, 1(2), 121-125.

Hamid, H., Nurhayati, B., \& Ali, A. (2014). The improvement of activity, the result of affective and cognitive learning to study biology through the implementation of brainbased learning model of grade VIIA student at SMPN 4 Sungguminasa in Gowa District. Jurnal Sainsmat, 3(1), 12-37. 
Inel, D., \& Balim, A.G. (2010). The effects of using problem-based learning in science and technology teaching upon students' academic achievement and levels of structuring concepts. Asia-Pacific Forum on Science Learning and Teaching, 11(2).

Jackman, W. M., \& Webb, J. M. (2019). Exploring gender differences in achievement through student voice: Critical insights and analyses. J Cogent Education, 6(1), 1-13.

Kanematsu, H., \& Barry, D. M. (2016). STEM and ICT education in intelligent environments. London: Springer.

Lestari, P, Ristanto, R. H., \& Miarsyah, M. (2019). Analysis of conceptual understanding of botany and metacognitive skill in pre-service biology teacher in Indonesia, Journal for the Education of Gifted Young Scientists, 7(2), 199-214.

Mahanal, S., Avila, S., \& Zubaidah, S. (2018). The potential of biology learning based on reading-concept map-cooperative script (REMAP-CS) and gender against critical thinking skills of Malang city high school students. Proceeding Biology Education Conference.

Mahapatra, S. (2015). Cognitive training and reading remediation. Journal of Education and Practice, 6(9), 57-63.

Muhlis. (2018). The effect of cooperative learning models on students' motivation and learning outcomes on the colloidal system material at SMAN 4 Bantimurung Maros. PEMBELAJAR: Jurnal Ilmu Pendidikan, Keguruan, dan Pembelajaran, 2(1), 12-24.

Niederle, M., \& Vesterlund, L. (2011). Gender and competition. Annual Review of Economics, 3, 601-630.

Nuraisah, E., \& Irawati, R., \& Hanifah, N. (2016). The difference in the influence of the use of conventional learning and contextual approaches to the ability to think critically mathematically and student motivation to learn on fraction material. Jurnal Pena Ilmiah, 1(1), 291-300.

Purwaningsih, I., Mahanal, S., Prasetyo, I. P., \& Zubaidah, S. (2017). The effect of the reading learning concept concept map numbered heads together and gender on the critical thinking skills of class X SMAN 10 Malang students. Proceeding Seminar Pend. IPA Pascasarjana UM, 2, 466-473.

Rachmatullah, A., Diana, S., \& Ha, M. (2017). The effects of curriculum, gender and students'favorite science subject on Indonesian high-school students' conceptions of learning science. Journal of Baltic Science Education, 16(5), 797-812.

Saban Y., Aydoğdu, B., \& Elmas, R. (2019). Achievement and gender effects on 5th grader's acquisition of science process skills in a socioeconomically disadvantaged neighborhood. Journal of Baltic Science Education, 18(4), 607-619. 
Saputra, M. D., Joyoatmojo, S., Wardani, D. K., \& Sangka, K. B. (2019). Developing critical-thinking skills through the collaboration of jigsaw model with problem-based learning model. International Journal of Instruction, 12(1), 1077-1094.

Vassilou, A. (2009). Gender differences in educational outcomes. Europe: Euridice. 